\title{
Prevalence of HIV, syphilis, hepatitis B and C among adults with mental illness: a multicenter
} study in Brazil

Prevalência de HIV, sífilis, hepatites B e C entre adultos com transtornos mentais: um estudo multicêntrico no Brasil

\author{
Mark Drew Crosland Guimarães ${ }^{1}$, Lorenza Nogueira Campos ${ }^{1}$, \\ Ana Paula Souto Melo ${ }^{1,2}$, Ricardo Andrade Carmo ${ }^{3}$, Carla Jorge Machado 4 , \\ Francisco de Assis Acurcio ${ }^{5}$, for the PESSOAS Project Network Group ${ }^{6}$
}

\begin{abstract}
Objective: There is evidence that patients with mental illness have increased prevalence of sexually transmitted infections, but data in Brazil are scarce. The objective of this study was to determine the prevalence of HIV, hepatitis $C$ and B, and syphilis among patients with mental illness in Brazil. Method: A multicenter representative sample of adults with mental illness was randomly selected from 26 mental health institutions throughout Brazil. Sociodemographic, sexual behavior and clinical data were obtained from person-to-person interviews and blood was collected for serology testing. Seroprevalence with $95 \%$ confidence limits were obtained correcting for sampling scheme. Results: Of the 2,475 patients interviewed, 2,238 had blood collected. Most participants were sexually active ever (88.8\%) or in the last 6 months (61.6\%), female (51.9\%), and single (66.6\%). Half of the sample had less than 5 years of schooling and the mean monthly individual income was low (US\$210.00). Condom use was very low either during lifetime (8\%) or in the last 6 months (16\%). Overall seroprevalence were 1.12\%, 0.80\%, 1.64\%, 14.7\% and 2.63\% for, respectively, syphilis, HIV, HBsAg, anti-HBc and anti-HCV. Conclusions: Seroprevalences found were higher than other populations with representative studies in Brazil, with high rates of sexual risk behavior. This is of public health concern, and prevention and care strategies for sexually transmitted infections among psychiatric patients should urgently be implemented by health authorities.
\end{abstract}

Descriptors: Mental disorders; HIV seroprevalence; Syphilis; Multicenter study; Hepatitis B

\section{Resumo}

Objetivo: Evidências indicam que pacientes com transtornos mentais têm elevada prevalência de infecções sexualmente transmissíveis, mas dados brasileiros são escassos. O objetivo deste estudo foi determinar a prevalência do HIV, hepatites $C$ e B, e sífilis entre pacientes com transtornos mentais no Brasil. Método: Uma amostra representativa de pacientes adultos com transtornos mentais foi aleatoriamente selecionada de instituições públicas de saúde mental no Brasil. Dados sociodemográficos, comportamentais e clínicos foram obtidos por entrevista face-a-face e sangue foi coletado para exames sorológicos. Soroprevalências com intervalo de $95 \%$ de confiança foram obtidas com correção para o esquema amostral. Resultados: Dos 2.475 pacientes entrevistados, 2.238 tiveram sangue coletado. A maioria era sexualmente ativa ao longo da vida (88,8\%) ou nos últimos seis meses (61,4\%), do gênero feminino (51,9\%), solteira (66,6\%), com metade dos participantes com menos de cinco anos de escolaridade e renda média mensal baixa individual (US\$210). Uso de preservativo foi baixo em toda a vida (8\%) ou nos últimos seis (16\%). As soroprevalências gerais foram 1,12\%, 0,80\%, 1,64\%, $14,7 \%$ e 2,63\% para, respectivamente, sifilis, HIV, HBsAg, anti-HBc e anti-HCV. Conclusões: As soroprevalências encontradas são maiores do que outros estudos com populações representativas no Brasil, com altos índices de comportamento sexual de risco. Isto é preocupante e estratégias de prevenção e cuidado para as infecções sexualmente transmissíveis entre pacientes psiquiátricos devem ser urgentemente implementadas pelos serviços de saúde.

Descritores: Transtornos mentais; Soroprevalência de HIV; Sífilis; Estudo multicêntrico; Hepatite B

1 Department of Preventive and Social Medicine, School of Medicine, Universidade Federal de Minas Gerais (UFMG), Belo Horizonte (MG), Brazil

2 Raul Soares Institute and Teaching Hospital, State Health Department, Belo Horizonte (MG), Brazil

3 Eduardo de Menezes Hospital, State Health Department, Belo Horizonte (MG), Brazil

4 Center of Regional Development and Planning, School of Economic Sciences, Universidade Federal de Minas Gerais (UFMG), Belo Horizonte (MG), Brazil

5 Department of Social Pharmacy, School of Pharmacy, Universidade Federal de Minas Gerais (UFMG), Belo Horizonte (MG), Brazil 


\section{Introduction}

The Brazilian National STD/AIDS Program has developed an integral and universal approach, i.e., curative, preventive and promotional aspects, in providing care for those with HIV infection, with widely international recognition ${ }^{1}$. In addition, the development of surveillance tools for monitoring the dissemination of HIV infection and other sexually transmitted infections (STI) to vulnerable populations has been a priority ${ }^{2}$. Studies with national representative samples have been conducted among pregnant women ${ }^{3,4}$, military recruits ${ }^{5}$, and more recently studies among men who have sex with men, female sex workers and injecting drug users (IDU) are currently under way in 10 major Brazilian metropolitan areas ${ }^{6}$.

There is evidence that patients with mental illness have increased prevalence of STI, including HIV, with rates varying from $3 \%$ to $22 \%^{7}$. However, most of these seroprevalence studies have been conducted in developed countries among patients with severe mental illness (SMI), i.e., schizophrenia, bipolar disorders and depression with psychotic symptoms ${ }^{8}$, or in mental health care facilities which over represent populations with substance use disorders and IDU. As a consequence, seroprevalence and behavioral characteristics may either be overestimated or lack representativeness to warrant estimates with more reliable external validity. Therefore, STI seroprevalence studies that target patients with greater variety of psychiatric conditions are highly desirable and much needed.

In Brazil, data on both seroprevalence of STI and risk behavior among patients with mental illness are scarce and there is none with a national representative sample of patients with general psychiatric diagnoses. Consonant with its policy, the Brazilian National STD/AIDS Program, in collaboration with the National Mental Health Coordination and the Universidade Federal de Minas Gerais, launched a study designed to assess risk behavior and STI/HIV prevalence among patients with mental illness under public hospital or outpatient care, namely PESSOAS Project (HIV Seroprevalence Survey in Mental Health). The aim of this brief communication is to describe the seroprevalence of HIV, syphilis, hepatitis $\mathrm{B}$ and $\mathrm{C}$ from PESSOAS Project and compare these rates to other representative data in Brazil.

\section{Method}

This is a cross-sectional national multicenter study conducted in 11 public psychiatric hospitals and in 15 public mental health outpatient clinics (CAPS) in Brazil. Because we aimed at obtaining a wider representation of adult patients with mental illness, participants were randomly selected regardless of their psychiatric diagnosis. In addition, we excluded Alcohol and Drug Addiction CAPS Centers (CAPSAd) due to the possibility of overestimating selected risk behaviors and/or prevalence rates, considering the concentration of substance use diagnoses and/or IDU in these centers, highly correlated with HIV infection. Thus, our eligibility criteria included adult (18+ years old) psychiatric patients under care either at hospitals or adult CAPS, who were capable of providing written informed consent, and were able to answer the questionnaire. Ethical approval was obtained from each site, the Universidade Federal de Minas Gerais (UFMG/ETIC 125/03) and the National Ethical Review Board (CONEP 592/2006). Methodological details can be found elsewhere ${ }^{9}$.

The sample size was estimated in 2,401 patients and it was proportionally stratified by type of center - hospital or CAPS, yielding framing fractions of $38 \%$ and $62 \%$, respectively. We anticipated $60 \%$ participation rate, resulting in 3,362 patients to be initially recruited. Within each type of center stratum, the sample size was proportionally distributed by the Brazilian geographical Regions according to the number of AIDS cases reported to the Ministry of Health as follows: $2 \%, 9 \%, 16 \%, 69 \%$ and 5\% for, respectively, the North, Northeast, South, Southeast and Central-West Regions. A two-stage probability sampling frame was used. First, the centers were randomly selected proportionally to the number of beds for the hospital stratum or the number of registered patients for the CAPS stratum within each region. The second sampling stage was carried out by selecting patients using simple random probability frame from each site 9 .

The protocol, questionnaires and procedures were tested and validated in a pilot study, previously described ${ }^{10}$. A preliminary assessment was carried out by mental health professionals in order to evaluate the subjects' ability to participate. Seven objective questions (patient's name, three words to be repeated immediately and later, day of the week, month and year, name of the place they were, simple math calculation) adapted from the Mini Mental State Examination were asked. Also, a qualitative assessment was carried out for the presence of delusional symptoms, acute psychosis and degree of mental retardation. Final judgment was based on the overall assessment, and those capable and eligible were invited to participate. A seven-day period was allowed for clinical stabilization of hospitalized patients.

A semi-structured person-to-person interview, tested and previously described ${ }^{10}$, was conducted for obtaining sociodemographic, clinical and behavioral data. Interviews were administered by experienced mental health care professionals. Psychiatric diagnoses and other medical comorbidities were obtained from medical charts and were grouped according to the International Classification of Diseases (ICD-10).

Serology testing for HIV, hepatitis B and C and syphilis was conducted using standard markers for Hepatitis B Surface Antigen (HBsAg) (ELISA), Hepatitis B Total Antibody (Anti-HBc) (ELISA), Hepatitis C antibody (Anti-HCV) (ELISA), HIV antibody (Anti-HIV 1 e 2) (ELISA) confirmed by Western Blot and Syphilis (VDRL, confirmed with Hemagglutinin). Blood was collected by local health professionals after counseling and frozen sera were referred to Ezequiel Dias Foundation Laboratory, Belo Horizonte-MG, where they were checked for quality control and processed for exams.

The seroprevalence of each infection was estimated by dividing the number of positive tests by the total number of tested participants. These estimates and their corresponding 95\% confidence interval were adjusted for within-cluster correlation considering each center as a potential cluster. Point estimates were proportionally weighted by the sample size of each site relative to its total population, i.e. number of beds or number of registered patients. Participants and non-participants were compared with regard to schooling, age, gender, psychiatric diagnosis and type of center (hospital or CAPS) using Pearson's Chi-Square test, and all analyses were carried out using $\mathrm{SAS}^{\circledR}$ and Stata $^{\circledR}$.

\section{Results}

Among the 3,255 recruited patients, 492 (15\%) were not capable of participating according to the preliminary assessment and 2,763 (85\%) were actually invited to participate. Among these, 2,475 were interviewed (90\%), 2,300 had blood collected (83\%), while $2,238(81 \%)$ had both interviews and blood collected and 288 were non-participants (10\%). Reasons for non-participation were refusals (52\%), not being located (19\%), missed appointments (8\%), non-eligible (4\%), legally incapable ( $1 \%)$, death $(0.7 \%)$, only blood collected $(0.7 \%)$, and others $(13 \%)$. There was no difference 
between participant and non-participant with regard to schooling $(p=0.07)$, age $(p=0.593)$, gender $(p=0.276)$ or psychiatric diagnosis ( $p=0.551)$. However, hospital patients had a higher participation rate as compared to CAPS ( $p<0.01$ ). Eighty-one percent of the centers ( $n=21$ ) were public institutions, while the remaining were private with partial public funding. A detailed description of the centers can be found elsewhere ${ }^{11}$.

Most participants were 40 or older (55.5\%), female (51.9\%), single $(66.6 \%)$, while mean monthly individual income was US\$210.00. Half of the sample had less than 5 years of schooling and $18.5 \%$ were not able to read or write. Ever use of cigarette, alcohol, any illicit drug or injection drug were reported by $71.0 \%$, $64.1 \%, 24.8 \%$ and $3.0 \%$ of participants, respectively. Most patients had been sexually active ever $(88.8 \%)$ or in the last 6 months (61.6\%). Only $8.0 \%$ and $16.1 \%$ reported always using condoms during their lifetime or in the past 6 months, respectively, while $61.5 \%$ had more than one sexual partner ever. Schizophrenia and other psychotic disorders were the most common diagnoses (47.3\%) followed by depression (13.3\%), bipolar disorder $(9.0 \%)$, substance use (7.0\%), and anxiety (3.6\%), while $58.1 \%$ had at least one previous psychiatric hospitalization. Finally, $22.0 \%$ had any medical comorbidity registered in the medical charts, $24.0 \%$ had a history of STI, $45.4 \%$ had a low level of knowledge regarding HIV/AIDS and $55.9 \%$ perceived themselves as not being at risk for HIV/AIDS.

Overall seroprevalence was $0.80 \%$ for anti-HIV, $1.1 \%$ for syphilis, $1.6 \%$ for $\mathrm{HBsAg}$, and $2.63 \%$ for anti-HCV, while the prevalence of anti-HBc, a marker for previous exposure to hepatitis B, was much higher (14.7\%) (Table 1). Compared to other studies with national samples in Brazil, the prevalence of HIV among our sample was one time higher than pregnant women $(0.4 \%)$ and almost eight times higher than military recruits $(0.09 \%)^{3,5,12-18}$. In addition,
HIV prevalence was higher than all other large studies, as well as the national estimate for the adult Brazilian population $(0.61 \%)$. The prevalence of all hepatitis $\mathrm{C}$ and $\mathrm{B}$ markers were also higher, including a representative sample of the general population of São Paulo City $(\mathrm{HCV}=1.42 \% \text { and anti-HBc }=5.9 \%)^{12}$.

\section{Discussion}

This is the first known national representative seroprevalence study of STI/HIV among patients with mental illness in Brazil. The point prevalence of HIV, syphilis, hepatitis B and C were shown to be higher when comparing to other Brazilian studies with probability samples of non-psychiatric populations, although some estimates were within the $95 \%$ confidence limits. Severe mental health conditions with lower perception of risk and cognitive impairment could partially explain these findings ${ }^{7,19,20}$. Also, lower socioeconomic conditions, lack of social support and poor access to health care may add to the burden of other medical conditions, including STI, to psychiatric patients ${ }^{7,20}$. Our rates tended to be lower than those found among SMI patients in developed countries $(3 \%-22 \%)^{7}$, particularly the USA, where studies tend to include younger and more severe mentally ill patients, usually recruited from one or a few psychiatric institutions with no clear geographical or population basis ${ }^{1}$. Similarly, studies carried out in Brazil among other populations may have been too specific in their age and/ or gender definitions or eligibility criteria (i.e., military recruits or pregnant women).

Our sample covered inpatients and outpatients from all five Brazilian Regions with a greater variety of psychiatric diagnoses. However, because these were abstracted from medical records from a variety of services, interpretations should be cautious. We also restricted our sample to patients receiving care at the time of the survey and who were capable of participating and this could

Table 1 - Selected comparison of prevalence data for HIV, Hepatitis B, Hepatitis C and syphilis, Brazil

\begin{tabular}{|c|c|c|c|c|c|c|c|c|c|}
\hline Author, year & Population & $\begin{array}{c}\text { Geographical } \\
\text { region }\end{array}$ & Type of sample & $\mathrm{N}$ & Syphilis & HIV & HBsAg & Anti-HBc & Anti-HCV \\
\hline & $\begin{array}{l}\text { PESSOAS } \\
\text { Project }\end{array}$ & Brazil & $\begin{array}{l}\text { National probability } \\
\text { sample }\end{array}$ & 2,338 & $\begin{array}{c}1.1 \% \\
(0.6-2.1)\end{array}$ & $\begin{array}{c}0.8 \% \\
(0.4-1.8)\end{array}$ & $\begin{array}{c}1.6 \% \\
(1.0-2.6)\end{array}$ & $\begin{array}{c}14.7 \% \\
(10.9-9.8)\end{array}$ & $\begin{array}{c}2.6 \% \\
(1.7-4.1)\end{array}$ \\
\hline $\begin{array}{l}\text { Szwarcwald, } \\
2006^{4}\end{array}$ & General & Brazil & Estimate & - & - & $0.61 \%$ & - & - & - \\
\hline $\begin{array}{l}\text { Rodrigues, } \\
2004^{3}\end{array}$ & $\begin{array}{l}\text { Expectant } \\
\text { mother }\end{array}$ & Brazil & $\begin{array}{l}\text { National probability } \\
\text { sample }\end{array}$ & 3,047 & $1.7 \%$ & - & - & - & - \\
\hline $\begin{array}{l}\text { Szwarcwald, } \\
2006^{4}\end{array}$ & $\begin{array}{l}\text { Pregnant } \\
\text { women }\end{array}$ & Brazil & $\begin{array}{l}\text { National probability } \\
\text { sample }\end{array}$ & 19,800 & - & $0.4 \%$ & - & - & - \\
\hline $\begin{array}{l}\text { Szwarcwald, } \\
2005^{5}\end{array}$ & $\begin{array}{l}\text { Military recruits } \\
17-21 \text { y.o. }\end{array}$ & Brazil & $\begin{array}{l}\text { National probability } \\
\text { sample }\end{array}$ & 30,970 & $0.9 \%$ & $0.09 \%$ & - & - & - \\
\hline Toledo, $2005^{18}$ & $\begin{array}{l}\text { Military recruits } \\
17-21 \text { y.o. }\end{array}$ & Brazil & $\begin{array}{l}\text { National probability } \\
\text { sample }\end{array}$ & 7,372 & - & - & - & - & $1.5 \%$ \\
\hline $\begin{array}{l}\text { Focaccia, } \\
1998^{12}\end{array}$ & General & São Paulo-SP & $\begin{array}{l}\text { Municipality } \\
\text { probability sample }\end{array}$ & 1,059 & - & - & $1.04 \%$ & $5.9 \%$ & $1.42 \%$ \\
\hline $\begin{array}{l}\text { Dourado, } \\
2007^{14}\end{array}$ & General & Salvador-BA & $\begin{array}{l}\text { Municipality } \\
\text { probability sample }\end{array}$ & 3,437 & - & $0.55 \%$ & - & - & - \\
\hline $\begin{array}{l}\text { Figueiró-Filho, } \\
2007^{13}\end{array}$ & $\begin{array}{l}\text { Pregnant } \\
\text { women }\end{array}$ & Campo Grande-MS & $\begin{array}{l}\text { All women in prenatal } \\
\text { care }\end{array}$ & 32,512 & $0.8 \%$ & $0.2 \%$ & $0.3 \%$ & - & $0.1 \%$ \\
\hline $\begin{array}{l}\text { De Souza, } \\
2004^{15}\end{array}$ & $\begin{array}{l}\text { Pregnant } \\
\text { women }\end{array}$ & MS & $\begin{array}{l}\text { Screened pregnant } \\
\text { women }\end{array}$ & 8,477 & $0.8 \%$ & $0.25 \%$ & $0.26 \%$ & - & - \\
\hline $\begin{array}{l}\text { Nascimento, } \\
2008^{16}\end{array}$ & Blood donors & $\begin{array}{l}\text { São Paulo, Salvador, } \\
\text { Manaus-AM }\end{array}$ & $\begin{array}{l}\text { First time unpaid } \\
\text { donors }\end{array}$ & 3,598 & - & - & $0.35 \%$ & $4.6 \%$ & $0.58 \%$ \\
\hline Reiche, $2000^{17}$ & $\begin{array}{l}\text { Pregnant } \\
\text { women }\end{array}$ & Londrina-PR & $\begin{array}{l}\text { Screened pregnant } \\
\text { women }\end{array}$ & 1,515 & $1.6 \%$ & $0.6 \%$ & $0.8 \%$ & - & $0.8 \%$ \\
\hline
\end{tabular}

*95\% Confidence Interval 
potentially underestimate the prevalence and behavior estimates.

Our study population also had similar age and gender distribution, as compared to the general Brazilian population. However, there was a higher proportion of participants who were black (16\%), illiterate (18.5\%), had less than 4 years of schooling (34.4\%) and a lower mean individual income (US\$210.00), as compared to the Brazilian census $(6 \%, 11.8 \%, 23.7 \%$, mean $=$ US\$388.00, respectively $)^{21}$. This may indicate that social inequality should be addressed by public health authorities in developing STI prevention and care strategies for this population in Brazil. More studies are needed to further explore potential causal relationships with STI among patients with mental illness.

Finally, we indicate that adults with mental illness in Brazil are at increased risk for STI compared to other population groups. There is an urgent need of developing public health policies towards providing a more comprehensive and integrated health care and prevention strategies for these patients. However, more representative studies worldwide are needed to improve and generate more precise risk behavior and STI prevalence rates for cross-country comparisons among mentally ill patients.

\section{Acknowledgments}

Financing: Brazilian National STD/AIDS Program, Ministry of Health (Financial Support: UNESCO/DST-Aids 914/BRA/1101 - Project 086/05). Dr. Guimarães was granted a Visiting Scholar Fellowship from CAPES (Brazilian Graduate Coordination, Ministry of Education).

The authors state no conflicts of interest, including specific financial interests and relationships and affiliations relevant to the subject of their manuscript.

${ }^{6}$ We are deeply indebted to all PESSOAS Project Network Group: Ana Maria Amaral Ragazzi, CERSAM César Campos, Betim, MG Ana Maria Damian Souto, CAPS Nossa Casa, Santiago, RS Ana Paula Souto Melo, Instistuto Raul Soares, FHEMIG

Carla Jorge Machado, Universidade Federal de Minas Gerais

Cassiane Echevenguá dos Santos Amaral, Casa Vida, Capão do Leão, RS Celso Aparecido Fattori Júnior, Mental Medicina Especializada, Sorocaba, SP
Edgar Rodrigues, CAPS Assis, Assis, SP

Flávia Fernanda de Oliveira, Clínica São Bento Menni, Divinópolis, MG

Florence Hostalácio Freitas, CAPS Formiga, Formiga, MG

Francisca Gerlane Sarmento de Oliveira, Hosp. Col. Dr. João Machado, Natal, RN

Francisco de Assis Acúrcio, Faculdade de Farmácia, UFMG

Hanna Karine de Carvalho, CAPS Morada Nova, Morada Nova, CE

Helian Nunes de Oliveira, Instituto Raul Soares, FHEMIG

Heloísa Agnes Mendes Marra, Instituto Raul Soares, Belo Horizonte, MG Jackson Mattos Medrado, Hospital Psiquiátrico de Maringá, Maringá, PR Juliana Marcela Flausino, CAPS São José do Rio Pardo, S. J. do Rio Pardo, SP Juliane Macedo Ney da Silva, CAPS Vidativa, Anápolis, GO

Kátia Galbinksy, CGSM/DAPE/SAS/MS

Kelly Cristian Ribeiro Graeff, CAPS Cantagalo, Cantagalo, RJ

Lorenza Nogueira Campos, Universidade Federal de Minas Gerais Lucimar da Mota Alves, CAPS Paraíso, Paraíso,TO

Marcilene Cristina Fonseca, Hospital Galba Veloso, Belo Horizonte, MG

Maria Alice Saccani Scardoelli, SES/SP, Dept. Psiquiatria II, Franco da Rocha, SP

Maria Cristina Correa Lopes Hoffmann, CGSM/DAPE/SAS/MS

Maria das Graças Nunes Martins, Hosp. Psiquiátrico Eduardo Ribeiro, Manaus, AM

Maria Elizete Silva Penido, CAPS II José Foster Jr., Guarujá, SP

Maria Imaculada de Fátima Freitas, Universidade Federal de Minas Gerais

Maria Tereza Gomes da Silva, SPSES Hospital Clemente Ferreira, Lins, SP Mariângela Cherchiglia, Universidade Federal de Minas Gerais

Mark Drew Crosland Guimarães, Universidade Federal de Minas Gerais

Murillo Mascarenhas Nascente, Clínica Isabela, Goiânia, GO

Renata Cristina de Souza Ramos, CAPS Renascer, Ribeirão das Neves, MG

Ricardo Andrade Carmo, Hospital Eduardo de Menezes, FHEMIG

Ronaldo Efigênio de Oliveira, CAPS Carmo, Carmo, RJ

Stanley Crosland Guimarães, CAPS Policlínica Dr. Hélio Sales, Montes Claros, MG

Suely Broxado de Oliveira, Instituto de Psiquiatria da UFRJ

Suely Maria Pinto Tozato, CAPS Francisco Morato, Francisco Morato, SP

Zelândia Marcheni Elizeche, Hosp. Psiquiátrico Vera Cruz, Sorocaba, SP

\section{Disclosures}

\begin{tabular}{|c|c|c|c|c|c|c|c|}
\hline $\begin{array}{l}\text { Writting group } \\
\text { member }\end{array}$ & Employment & $\begin{array}{l}\text { Research } \\
\text { grant }\end{array}$ & $\begin{array}{l}\text { Other research grant } \\
\text { or medical } \\
\text { continuous education }\end{array}$ & $\begin{array}{l}\text { Speaker's } \\
\text { honoraria }\end{array}$ & $\begin{array}{c}\text { Ownership } \\
\text { interest }\end{array}$ & $\begin{array}{l}\text { Consultant/ } \\
\text { Advisory } \\
\text { board }\end{array}$ & Other ${ }^{3}$ \\
\hline $\begin{array}{l}\text { Mark Drew Crosland } \\
\text { Guimarães }\end{array}$ & UFMG & -- & -- & $\ldots$ & -- & -- & -- \\
\hline $\begin{array}{l}\text { Lorenza Nogueira } \\
\text { Campos }\end{array}$ & UFMG & $\cdots$ & -- & $\ldots$ & - & $\cdots$ & -- \\
\hline Ana Paula Souto Melo & $\begin{array}{l}\text { Instituto Raul } \\
\text { Soares }\end{array}$ & -- & -- & $\ldots$ & -- & -- & -- \\
\hline Carla Jorge Machado & UFMG & -- & - & $\ldots$ & - & - & -- \\
\hline $\begin{array}{l}\text { Francisco de Assis } \\
\text { Acurcio }\end{array}$ & UFMG & -- & -- & $\ldots$ & -- & $\ldots$ & -- \\
\hline
\end{tabular}




\section{References}

1. Okie S. Fighting HIV - Lessons from Brazil. N Eng J Med. 2006;354(19): 1977-81.

2. Brasil, Ministério da Saúde, Programa Nacional de DST/Aids. 2008. [cited 2008 Jan 23] Available from: http://sistemas.aids. gov.br/ monitoraids2/aidsi/ frames.htm.

3. Rodrigues CS, Guimarães MD, Grupo Nacional de Estudo sobre Sífilis Congênita. Syphilis positivity in puerperal women: still a challenge in Brazil. Rev Panam Salud Publica. 2004;16(3):168-75.

4. Szwarcwald CL, Souza Júnior PR. Estimativa da prevalência de HIV na população brasileira de 15 a 49 anos, 2002. Programa Nacional de DST/Aids. Boletim Epidemiológico DST/AIDS. 2006;III(1):11-5.

5. Szwarcwald CL, de Carvalho MF, Barbosa Junior A, Barreira D, Speranza FA, de Castilho EA. Temporal trends of HIV-related risk behavior among Brazilian military conscripts, 1997-2000. Clinics. 2005;60(5):367-74.

6. Brasil, Ministério da Saúde, Programa Nacional de DST/Aids. [cited 2008 Jan 23] Available from; http://www.aids.gov.br/ data/Pages/ LUMIS02432COAPTBRIE.htm, on Jan 23, 2008.

7. Campos LN, Guimarães MD, Carmo RA, Melo AP, Oliveira HN, Elkington K, McKinnon K. HIV, syphilis and hepatitis B and C prevalence among patients with mental illness: a review of the literature. Cad Saude Publica. 2008;24(Suppl 4):s607-20.

8. Schinnar AP, Rothbard AB, Kanter R, Jung YS. An empirical literature review of definitions of severe and persistent mental illness. Am J Psychiatry. 1990;147(12):1602-8.

9. Guimarães MDC, Acurcio FA, Possas CA, De Sá, M. Organizadores. Prevenção e atenção às IST/Aids na saúde mental no Brasil: Análises, desafios e perspectivas - Projeto PESSOAS. Série pesquisas, Estudos e avaliação n 11 Brasília: Editora ASCOM, Ministério da Saúde. 200p. No prelo 2008

10. Guimarães MD, Oliveira HN, Campos LN, Santos CA, Gomes CE, Oliveira SB, Freitas MI, Acurcio FA, Machado CJ. Reliability and validity of a questionnaire on vulnerability to sexually transmitted infections among adults with chronic mental illness - PESSOAS Project. Rev Bras Psiquiatr. 2008;30(1):55-9.

11. Melo AP, Acurcio FA, Cherchiglia ML, Veloso CC, Guimarães MD. Evaluation of mental health services: care and prevention of sexually transmitted diseases within PESSOAS(*) Project context. Rev Med Minas Gerais. 2007;17(1/2 Suppl 4): S240-8.

12. Focaccia R, da Conceição OJ, Sette H Jr, Sabino E, Bassit L, Nitrini DR, Lomar AV, Lourenço R, Vieira de Souza F, Kiffer CR, Santos EB, Gonzales MP, Sáez-Alquézar A, Riscal JR, Fischer D. Estimated prevalence of viral hepatitis in the general population of the municipality of São Paulo, measured by a serologic survey of a stratified, randomized and residence-based population. Braz J Infect Dis. 1998;2(6):269-84.

13. Figueiró-Filho EA, Senefonte FR, Lopes AH, de Morais OO, Souza Júnior VG, Maia TL, Duarte G. Frequency of HIV-1, rubella, syphilis, toxoplasmosis, cytomegalovirus, simple herpes virus, hepatitis $B$, hepatitis C, Chagas disease and HTLV I/II infection in pregnant women of State of Mato Grosso do Sul. Rev Soc Bras Med Trop. 2007;40(2):181-7.

14. Dourado I, Milroy CA, Mello MA, Ferraro GA, Castro-Lima Filho $\mathrm{H}$ Guimarães ML, Morgado MG, Teixeira MG, Barreto ML, GalvãoCastro B. HIV-1 seroprevalence in the general population of Salvador, Bahia State, Northeast Brazil. Cad Saude Publica. 2007;23(1):2532.

15. De Souza NC, Botelho CA, Honer MR. Retrospective study of a pioneer antenatal screening program with 8,477 pregnant women in Brazil. Clin Exp Obstet Gynecol. 2004;31(3):217-20.

16. Nascimento MC, Mayaud P, Sabino EC, Torres KL, Franceschi S. Prevalence of hepatitis $B$ and $C$ serological markers among firsttime blood donors in Brazil: a multi-center serosurvey. J Med Virol. 2008;80(1):53-7.

17. Reiche EM, Morimoto HK, Farias GN, Hisatsugu KR, Geller L, Gomes AC, Inoue Y, Rodrigues G, Matsuo T. Prevalence of American trypanosomiasis, syphilis, toxoplasmosis, rubella, hepatitis $B$, hepatitis C, human immunodeficiency virus infection, assayed through serological tests among pregnant patients, from 1996 to 1998, at the Regional University Hospital Norte do Paraná. Rev Soc Bras Med Trop. 2000;33(6):519-527.
18. Toledo AC Jr, Greco DB, Felga M, Barreira D, Gadelha MF, Speranza FA. Seroprevalence of hepatitis B and C in Brazilian army conscripts in 2002: a cross-sectional study. Braz J Infect Dis. 2005;9(5): 374-83.

19. Wainberg ML, Alfredo González M, McKinnon K, Elkington KS, Pinto D, Gruber Mann C, Mattos PE. Targeted ethnography as a critical step to inform cultural adaptations of HIV prevention interventions for adults with severe mental illness. Soc Sci Med. 2007;65(2): 296-308.

20. Collins PY, Holam AR, Freeman MC, Patel V. What is the relevance of mental health to HIV/AIDS care and treatment programs in developing countries? A systematic review. AIDS. 2006;20(12):1571-82.

21. IBGE, Pesquisa Nacional por Amostra de Domicílios (PNAD) [National Household Sample Survey], Brasilia, 2006. [cited 2008 Jan 15] Available from: http://www.ibge.gov.br/home/ estatistica/ populacao/trabalhoerendimento/pnad2006/sintesepnad2006.pdf. 